\title{
The Validation of New Formula of Islamic Home Financing Among Finance Expertise's
}

\author{
Puspa Liza Binti Ghazali ${ }^{a^{*}}$ and Sharifah Arni binti Syed Jaaffar ${ }^{\mathbf{a}}$ \\ ${ }^{a}$ Faculty of Economic and Management Science, Universiti Sultan Zainal Abidin, 21300 Kuala Nerus, \\ Terengganu. MALAYSIA. \\ *Corresponding author email: puspaliza@unisza.edu.my
}

\begin{abstract}
Islamic banks in Malaysia practiced a different type of shariah principle that may offer advantage and disadvantages to Islamic home financing's customer. Instead of analyzing the percentage of acceptance to Barakah Model Islamic home financing among public, a set of questionnaires were distributed among Islamic financial expertise. Barakah model need to be validate as to check it is fit according to Islamic finance's need or not. The Barakah model is designed to cater the lower income earners especially RM 3500 and below with extra benefit to protect the house owner if anything happens in future.
\end{abstract}

Keywords: Islamic Home Financing, Shariah Principle, Barakah Model, Islamic financial expertise

\section{Introduction}

On certain part in Malaysia that is in Labuan, the officers are conversant with Islamic banking principal and practices (Ricardo and Hanudin, 2009). Salman and Charles (2011) in his study stated that national culture would affect the provider's service quality in takaful industry as an alternate to the conventional insurance for the purpose of adding knowledge and to fill the gap in the literature. The researcher will generate hypotheses to be tested quantitatively and also build a preliminary model that can work as a seed for further research to add to the anemic literature by studying the effect of national culture based on power distance and uncertainty avoidance on service provision in terms of information flow and communication policy. Reviewing the literature revealed an existing conceptual framework that provides a theoretical background between service quality and national culture through some service mechanisms. However, the relations needs to be tested statistically to substantiate the effect as to what extent national culture effects service provision in terms of information flow and communication policy. 
Khalid (2015) in his study comprehend that manager should focus on enhancing the efficiency of their firms by look out the operating status of the GCC Takaful industry for the guidelines of efficiency. Thus, manager can use it to improve the overall insurance industry market and at the same time the efficiency of each supplier can be determine.

\section{Literature Review}

Ghazali et al., (2011, 2012a, 2012b, 2012c, 2015 and 2017) had study the gap of existing model and come out with the new model of education plan that combine the riders in one plan and named as 'Economic Education Plan' takaful. The plan should emphasis on having health, accident, hospital costs, loss an effort to work, critical illnesses, education, death benefit, and death coverage and also pension. The importance of life insurance in family takaful category is a must for each citizen, consequence to that the product needs to be affording by all income earners.

The Islamic financial institution has applied an agreed principle in their business each of the existing principles contains its own strengths and weaknesses. Consequences from that study, the new Islamic home financing have been introduced just to cater the lower income starts from RM 3,000 per month and below to enjoy the facility of RM 200,000 with acceptable instalment (Syed et al, 2017).

\section{Methodolgy}

The expertises that participate in this survey is manager or to be specific is branch manager in Islamic financial instituition (IFI) and sales executive. Both of the category is choose to complete the survey as the know the product very well and the education background is at least bachelor degree level. They participate in the marketing of the product and offer the product to the customers. The questionnaire is distribution among the expertise among branch manager and sales executive as in Table 1 to validate the result of the new product by using another questionnaire which will be used this product one day. The validation of the new Barakah home financing formula is to be validated among expertise whether the accepted or not among them.

\section{New Home Financing Model (Barakah Model)}

Concept of buying the house with the price is $\mathrm{P}$ and the profit is not more than the $1 / 3$ of the price. According to Az-Zuhaili (2014), Islam basically has no standard restrictions or standards on profit-making. The merchant is free to determine the desired profit of an item. However, a blessing benefit (Barakah Model) is a profit that does not exceed one-third of the price of capital. But in Barakah, we used a quarter profit from principal financing because to make sure the profit gain do not exceed one third of the principal. Only the profit the formula will be derivation (Ghazali et al., 2011) as follows: 
Table 1: Interview Result of Expert Viewers

\begin{tabular}{|c|c|c|c|c|c|c|c|c|c|c|c|c|c|c|c|c|c|c|c|c|c|}
\hline \multirow[t]{3}{*}{ No } & \multirow[t]{3}{*}{ Questions } & \multicolumn{20}{|c|}{ Name of the Expert Viewer } \\
\hline & & \multicolumn{2}{|c|}{ Nik } & \multicolumn{2}{|c|}{ Fauzul } & \multicolumn{2}{|c|}{ Fadzil } & \multicolumn{2}{|c|}{ Razarrudin } & \multicolumn{2}{|c|}{ Hidayah } & \multicolumn{2}{|c|}{ Suhail } & \multicolumn{2}{|c|}{ Farah } & \multicolumn{2}{|c|}{ Fatimah } & \multicolumn{2}{|c|}{ Ahmad } & \multicolumn{2}{|l|}{ Ain } \\
\hline & & A & $\mathrm{D}$ & $\mathrm{A}$ & $\mathrm{D}$ & A & $\mathrm{D}$ & $\bar{A}$ & $\mathrm{D}$ & $\bar{A}$ & $\mathrm{D}$ & $\mathrm{A}$ & $\mathrm{D}$ & A & $\mathrm{D}$ & $\bar{A}$ & $\mathrm{D}$ & $\mathrm{A}$ & $\mathrm{D}$ & A & $\mathrm{D}$ \\
\hline 1 & $\begin{array}{l}\text { Does your bank offer } \\
\text { any Islamic home } \\
\text { financing product? }\end{array}$ & $\mathrm{Y}$ & & $\mathrm{Y}$ & & $\mathrm{Y}$ & & $\mathrm{Y}$ & & $\mathrm{Y}$ & & $\mathrm{Y}$ & & $\mathrm{Y}$ & & $\mathrm{Y}$ & & $\mathrm{Y}$ & & $\mathrm{Y}$ & \\
\hline 2 & $\begin{array}{l}\text { Does your Islamic home } \\
\text { financing product } \\
\text { enquire customer to pay } \\
\text { almost double the } \\
\text { amount of financing? }\end{array}$ & $\mathrm{Y}$ & & $\mathrm{Y}$ & & $\mathrm{Y}$ & & & $\mathrm{N}$ & & $\mathrm{N}$ & & $\mathrm{N}$ & $\mathrm{Y}$ & & & $\mathrm{N}$ & & $\mathrm{N}$ & & $\mathrm{N}$ \\
\hline 3 & $\begin{array}{l}\text { Do your bank offer } \\
\text { takaful that cover any } \\
\text { loss or lives or property } \\
\text { if anything happen to } \\
\text { financier? }\end{array}$ & $\mathrm{Y}$ & & $\mathrm{Y}$ & & $\mathrm{Y}$ & & $\mathrm{Y}$ & & $\mathrm{Y}$ & & $\mathrm{Y}$ & & $\mathrm{Y}$ & & $\mathrm{Y}$ & & $\mathrm{Y}$ & & $\mathrm{Y}$ & \\
\hline 4 & $\begin{array}{l}\text { Do you agree that } \\
\text { existing takaful } \\
\text { coverage is only on } \\
\text { death and total and } \\
\text { permanent disability } \\
\text { (TPD)? }\end{array}$ & $\mathrm{Y}$ & & $\mathrm{Y}$ & & Y & & $\mathrm{Y}$ & & $\mathrm{Y}$ & & $\mathrm{Y}$ & & $\mathrm{Y}$ & & $\mathrm{Y}$ & & $\mathrm{Y}$ & & $\mathrm{Y}$ & \\
\hline 5 & $\begin{array}{l}\text { What do you think if } \\
\text { new takaful model is } \\
\text { design just to improve } \\
\text { the existing coverage } \\
\text { into loss and effort to } \\
\text { work due to critical } \\
\text { illness, incidence or loss } \\
\text { income? }\end{array}$ & $\mathrm{Y}$ & & $\mathrm{Y}$ & & $\mathrm{Y}$ & & $\mathrm{Y}$ & & $\mathrm{Y}$ & & $\mathrm{Y}$ & & $\mathrm{Y}$ & & $\mathrm{Y}$ & & $\mathrm{Y}$ & & $\mathrm{Y}$ & \\
\hline 6 & $\begin{array}{l}\text { What do you think as a } \\
\text { banker if new takaful } \\
\text { model just take } 1 / 3 \text { of } \\
\text { profit, is it profitable to } \\
\text { the bank or not? }\end{array}$ & & $\mathrm{N}$ & $\mathrm{Y}$ & & & $\mathrm{N}$ & $\mathrm{Y}$ & & $\mathrm{Y}$ & & $\mathrm{Y}$ & & $\mathrm{Y}$ & & $\mathrm{Y}$ & & & $\mathrm{N}$ & & $\mathrm{N}$ \\
\hline 7 & $\begin{array}{l}\text { Through the eyes of } \\
\text { customers, if bank } \\
\text { propose a new takaful } \\
\text { model with only } 1 / 3 \text { of } \\
\text { profit, do you think the } \\
\text { customers will agree? }\end{array}$ & $\mathrm{Y}$ & & $\mathrm{Y}$ & & $\mathrm{Y}$ & & $\mathrm{Y}$ & & $\mathrm{Y}$ & & $\mathrm{Y}$ & & $\mathrm{Y}$ & & $\mathrm{Y}$ & & $\mathrm{Y}$ & & $\mathrm{Y}$ & \\
\hline 8 & $\begin{array}{l}\text { While offering a low } \\
\text { profit taken by the bank } \\
\text { and loss and effort to } \\
\text { work in conjunction of } \\
\text { existing features, do you } \\
\text { think both party will } \\
\text { enjoy the fair situation } \\
\text { in term of profit } \\
\text { sharing? }\end{array}$ & & $\mathrm{N}$ & $\mathrm{Y}$ & & & $\mathrm{N}$ & $\mathrm{Y}$ & & $\mathrm{Y}$ & & $\mathrm{Y}$ & & $\mathrm{Y}$ & & $\mathrm{Y}$ & & & $\mathrm{N}$ & & $\mathrm{N}$ \\
\hline
\end{tabular}

Derivation of Barakah Housing Loan $=$ Principal + Profit (one fourth of the principal)

$$
\begin{aligned}
& =\frac{\left[P+\frac{1}{4} P(1+r n)\right]}{n} \\
& =\frac{P+\frac{1}{4} P+\frac{P r n}{4}}{n}
\end{aligned}
$$




$$
\begin{aligned}
& =\frac{p\left(1+\frac{1}{4}+\frac{r n}{4}\right)}{n} \\
& =\frac{P}{n}\left[\frac{5+r n}{4}\right]
\end{aligned}
$$

Whereby,

$\mathrm{P}=$ Principal of total home financing

$\mathrm{r}=$ Profit rate per month

$\mathrm{n}=$ Periodic payment of home financing in month

\section{Result and Discussion}

A bank branch manager is accountable for the operation, administration, marketing, training, lending and security of a local bank branch. While on sales executives parts is to sell a company's products and services to individuals, businesses and government organizations. As well as approaching potential customers with the aim of winning new business, sales executives strive to maintain good relationships with existing clients, gaining repeat business wherever possible.

The branch managers that participate in this survey are Mr Nik, Mr Fauzul, Mr Fadzil and $\mathrm{Mr}$ Ahmad. While the rest of the respondent is sales executive which are En Razarrudin, Pn Hidayah, Pn Farah, Pn Suhaila, Pn Fatimah and Pn Ain. The total respondents are 10 people. There are 8 questions in total that is used to ask the expertise in validating the new product named as Barakah model. The question is categorized as yes or no question or in specific category is polar question that can be answered simply in the (yes) affirmative or (no) negative. These questions normally invert the subject and verb. This question usually found in three ranges, the first one is the inverted question, next is inverted question that offer an alternative to an answer and the last one is tag question. The example of inverted question is "Are you going?" While for inverted question with alternative is "Are you staying or going?" And for tag question is "You're going, aren't you?"

Normally, the researcher always use the yes no questions in polls and surveys, as it's more time consuming. Typically, researchers ask questions that will stimulate yes or no answers. According to the interview questions in the schedule above, the first question is fall under inverted question category: "Does your bank offer any Islamic home financing product? The percentage of agree to that question is $100 \%$. Mostly bank in Malaysia offer Islamic financing product to customers. For the next question, "Does your Islamic home financing product enquire customer to pay almost double the amount of financing? It can be categorized as tag question. As the researcher want the respondent or bank expertise to agree with the question. There are 4 expert viewers agree with the second question while 6 expert viewers disagree with the second question. So the percentage of agree are $40 \%$ and disagree : $60 \%$. The third questions is "Do your bank offer takaful that cover any loss or lives or property if anything happen to financier?" It is an inverted question. All the expert viewers agree with the third question. So the percentage of agree is $100 \%$. 
The fourth question is known as the tag question: "Do you agree that existing takaful coverage is only on death and total and permanent disability (TPD)?" While on this question, the percentage of agrees also $100 \%$. The fifth question is "What do you think if new takaful model is design just to improve the existing coverage into loss and effort to work due to critical illness, incidence or loss income? The question is under the category of inverted question with alternative. The percentages of agree is also $100 \%$.

The sixth question in a row is "What do you think as a banker if new takaful model just take 1/3 of profit, is it profitable to the bank or not?" This question also fall under the inverted question with alternatives as the question put the alternative of answers in the question. There are 6 expert viewers agree with the sixth question while 4 expert viewers disagree with the sixth question. The percentage of agree is $60 \%$ and disagree is $40 \%$. Next question in the survey is "Through the eyes of customers, if bank propose a new takaful model with only $1 / 3$ of profit, do you think the customers will agree? Same with the previous category, the question also falls under the inverted question with alternative. All the expert viewers agree with the seventh question. The percentage of agree is also $100 \%$. The last question is "While offering a low profit taken by the bank and loss and effort to work in conjunction of existing features, do you think both party will enjoy the fair situation in term of profit sharing?

The question shows an alternative to answer. There are 6 expert viewers agree with the eight question while 4 expert viewers disagree with the question. The percentage of agree is $60 \%$ and disagree $40 \%$. From the result show that average percentage of expert viewers which was agree with the questions were : $94.29 \%$. Meanwhile the average percentage of expert viewers which was disagree with the questions were $: 5.71 \%$. Therefore, the findings of this research had related to the interview result of expert viewers.

\section{Conclusion}

The main points that need to be avoided in Islamic home financing are riba (usury), maisir (gamble) and gharar (uncertainty). In the discussion, the respondent had noticed the insufficiency benefit offered in existing shariah principle applied in Islamic finance institution in Malaysia. Most of the respondents agreed on profit taken by the bank, which is only $1 / 3$ profit is taken by IFI will benefit both IFI and house owner.

\section{Acknowledgement}

I would like to thank to DPU Grant Scheme of Universiti Sultan Zainal Abidin because help us to finish this research. 


\section{References}

Alajmi, S. and Dennis, C., (2011). "The effect of national culture on information flow", European, Mediterranean \& Middle Eastern Conference on Information Systems 2011 (EMCIS2011), May 30-31 2011, Athens, Greece.

Az-Zuhaili, W. (2011). Fiqih Islam Wa Adillatuhu: Jihad, Pengadilan dan Mekanisme Mengambil Keputusan, Pemerintahan dalam Islam. Malang: Gema Insani

Ghazali, P. L., Mamat Mustafa, Omar, L., N. H. M. Foziah, D. A. Guci, Y. B. Abdullah and N. E. S. B. Sazali (2017). Medical Integration Model of Family takaful For Blue Collar. Far East Journal of Mathematical Sciences (FJMS), Volume 101, Number 6, 2017, Pages 1197-1205.

Ghazali, P. L., Mazlina, A. N., Izah, M. T., Maslina, M., Zulqurnaim, W. I., \& Mustafa, M. (2015). Optimization of integration model in family takaful. Journal of Applied Mathematics Sciences,9(39), 18991909.

Ghazali, P.L., Mohd, L., Ismail, M. and Mamat. and Wan Ahmad, W.M.A., (2012a). Integration Model in Premium Life Table of Family Takaful. Journal of Applied Sciences Research, 8(7), 3763-3776.

Ghazali, P.L., Mohd, L., Ismail, M. and Mamat. and Wan Ahmad, W.M.A., (2012b). Comparison Of Premium Life Tables Between Existing Model And Integration Model In Family Takaful. Journal of Applied Science (JAS), Volume 8, Issue 7, July 2012, pp. 3754-3762.

Ghazali, P.L., Mohd, L., Ismail, M. and Mamat. and Wan Ahmad, W.M.A., (2012c). Implementation of integration model for all. Journal of Applied Science (JAS), Volume 8, Issue 3, March 2012, pp. 1802-1812.

Ghazali, P. L., Mohd, I., Mamat, M. and Ahmad, W. M. A. (2011). Mathematical Modelling of Family Takaful. Journal of Applied Science (JAS), 11. pp. 3381-3388. ISSN 1812-5654.

Khalid Al-Amri, (2015) "Takaful insurance efficiency in the GCC countries", Humanomics, Vol. 31 Issue: 3, pp.344-353.

Ricardo Bab and Hanudin Amin, (2009) "Offshore bankers' perception on Islamic banking niche for Labuan: an analysis", International Journal of Commerce and Management, Vol. 19 Issue: 4, pp.293-308.

Sharifah Arni Syed Jaaffar, Puspa Liza Ghazali, Zainudin Awang and Nurfadhlina Abdul Halim (2017), "The weakness and strength of the mathematical formulation in existing shariah principle of Islamic home financing", World of Applied Sciences Journal, 35 (10): 2229-2234.. 